„Śląskie Studia Polonistyczne" 2019, nr 2 (14) ISSN 2353-0928 (wersja elektroniczna)

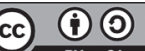

https://doi.org/10.31261/SSP.2019.14.12

\section{Paweł Kaczmarski}

\section{Wkurwy, złostki i pomiędzy \\ 0 wierszach Kamili Janiak}

Mało jest współczesnych poetek i poetów budzących tak wyraziste afektywne skojarzenia jak Kamila Janiak. W swoich wierszach autorkakto zabit bambi?operuje intensywnymi emocjami i nastrojami; nie chodzi o to, że mamy do czynienia z rozemocjonowanym podmiotem - łatwo byłoby tu osunąć się w seksistowską kliszę - ale o to, że dla poetki pociągającym, wartym krytycznej i analitycznej obróbki tematem są momenty afektywnej wyrazistości: szczególnych przesileń, napięć, dziwnych stanów. Janiak nie poddaje im się, ale literacko obrabia je w wierszu - emocjonalność jest nie tyle cechą, ile tematem tych wierszy. Dlatego tak często o polityczności Janiak mówi się w kategoriach wkurwu, oburzenia; dlatego te bardziej egzystencjalnie czy introwertycznie wychylone spośród jej wierszy mówią w poruszający sposób o depresji, panice, paranoi, momentach wyjątkowego osamotnienia i podmiotowego rozpadu.

W zasadzie cały ostatni tom poetki: wiersze przeciwko ludzkości, czytać należałoby w tej drugiej raczej niż w tej pierwszej perspektywie - to znacznie częściej wiersze o samotności i depresji niż o gniewie. Takie przesunięcie zaskakuje już ze względu na tytuł tomu - pisanie „przeciwko ludzkości” to przecież w poezji Janiak właśnie fundacja wkurwu, źródło frustracji i oburzenia. Wywiad z poetką, opublikowany przy okazji promocji antologii Zebrało się śliny - na trzy lata przed wierszami przeciwko ludzkości - zaczyna się od właśnie tej kwestii:

Maja Staśko: „kosmos potrzebuje mojego wkurwienia” pojawia się $\mathrm{w}$ jednym $\mathrm{z}$ wierszy Twojego nowego tomu, zwęglona jantar. Na co się wkurwiasz?

Kamila Janiak: W zasadzie na wszystko. To taka końcowa faza frustracji. Na głupotę, krótkowzroczność, na poczucie wyższości ludzi nad zwierzętami, światem i innymi ludźmi. Generalnie „nienawidzę ludzi”, a oni nienawidzą mnie. Trochę to przerysowane, ale w fazie końcowej frustracji wszystko jest komiksem. A kosmos się tym karmi (JANiAK, StAśko, [b.r.]).

W tym samym wywiadzie znajdziemy jeszcze inne podobne do tej deklaracje Janiak (JANIAK, STAŚKo, [b.r.]). Zbiegają się one zresztą 
z obserwacjami krytyków: Alina Świeściak, opisująca związki poetki z punkiem, wspominała o "buncie antyantropoicznym”, „W zgodzie z naturą, przeciw człowiekowi” (ŚwIEścıAK, 2018); opisując stan recepcji Janiak na rok 2016, Jakub Skurtys (w online'owej wersji szkicu pomieszczonego w Zebrało się śliny) zwracał uwagę na emocjonalnie wyraziste podsumowania krytyków (REDAKTOR BiBLIoteki, [b.r.]). Drapieżność, wulgarność, punk, „agresywne obrazowanie"1 , złość i mizantropia-Janiak w tej perspektywie jawi się jako poetka jednocześnie politycznie mocnego i egzystencjalnie przejmującego gniewu.

I nagle w wierszach przeciwko ludzkości nie odnajdujemy takich emocji prawie w ogóle. Nastrój książki - czyżby wręcz melancholijny? - określają takie na przykład wiersze:

\section{samotność}

w polsce nie czuła się samotna bardziej niż w innych miejscach.

istnienie świata doprowadzało ją na skraj bezradności, to nie strach, to niechęć.

(JANIAK, 2018, s. 27)

- lub:

\section{obraz morza nad łóżkiem na błękitnej ścianie}

regularnie jest falą

i rozbija się o brzeg.

cofa się półżywa i wściekła

i rozbija się o brzeg.

brzeg radzi sobie z nią świetnie.

(JANIAK, 2018, s. 30)

„Wściekła”, owszem, ale „półżywa” i bezradna, rzucona jak fala o brzeg. Nie znajdziemy tu ani owych słynnych wulgaryzmów Janiak, ani jej profetycznych tonów, ani porywających, wulgarnych (tym razem w niedosłownym sensie) wyliczeń ze zwęglonej jantar. Chociaż „zwęglenie” dokonało się właśnie tam, w poprzednim tomie, to w wierszach przeciwko ludzkości coś jakby dogasa - zamiast konotującej grozę i napięcie symboliki ognia znajdujemy na przykład obraz gruntu, „który dawno spłonął” (zimny maj-JANIAK, 2018, s. 43), ogień jako ślad, nieobecny, domyślany.

1 „[...] częścią wspólną tego wszystkiego jest wkurw, niedostosowanie, cynizm i smutek" (cyt. za: Kozioz, [b.r.]). 
Z jednej strony mizantropia wierszy przeciwko ludzkości, chociaż uparta, powracająca, okazuje się mało eksplozywna - chciałaby buchnąć płomieniem, ale nie może. Z drugiej strony trudno mówić o dokonującym się w nowym tomie definitywnym zerwaniu; nadal mamy do czynienia z tą samą, rozbitą na tysiąc niedokończonych narracji narratorką, tym samym osamotnieniem i tą samą depresją, tą samą Polską budzącą naraz niechęć i czułość; nadal dostajemy do rąk mieszankę piosenek i zwierzeń, rozbieganych skojarzeń i jukstapozycyjnych obrazków (chociaż, co warte uwagi, po raz pierwszy pojawiają się tu wiersze krótkie, kompaktowe, kilkuwersowe). Wiersze przeciwko ludzkości to na pierwszy, drugi i dziesiąty rzut oka książka Kamili Janiak. Na myśl nasuwa się więc, jak zwykle w taki wypadkach, pytanie: zmienił się głos poetki czy raczej punkt, z którego go słyszymy?

Wkurw jest jednym z wątków definiujących poezję Janiak, a przy tym bodaj najbardziej otwarcie politycznym elementem tej poezji. (Gdybym na etapie redakcji Zebrało się śliny miał powiedzieć, dlaczego razem z Martą Koronkiewicz zdecydowaliśmy o włączeniu do tomu wierszy autorki frajerom śmierć..., zapewne o wkurwie wspomniałbym w pierwszej kolejności). Muzyczna działalność autorki (wokalistki kilku różnych zespołów, określanych między innymi jako grunge'owe, industrialne, punkowe) narzuca porównania jej poezji ze wspomnianą punkową estetyką. Ale wiersze przeciwko ludzkości przypominają - czy, jak w przypadku niżej podpisanego, raczej ujawniają - że wkurwowi owemu daleko do politycznej modelowości: czy to w postaci czystego, niepowściągniętego buntu, czy etycznie motywowanego oburzenia, wynikającego z poczucia wspólnoty i solidarności. Ten gniew tli się raczej niż wybucha.

To, oczywiście, na tym etapie tylko przeczucie - intuicja, wrażenie - ale spójrzmy pod tak zarysowanym kątem na konkretne obrazy i wątki z pierwszych trzech książek Janiak, które z gniewem czy wkurwem moglibyśmy kojarzyć.

Przede wszystkim owa słynna (wracam tu do podsumowujących recepcję poezji Janiak rozpoznań Skurtysa) wulgarność - inwektywy i wulgaryzmy używane często i, co kluczowe, jakby od niechcenia. A może raczej: z pewną rezygnacją; inaczej bowiem niż sygnalizował to frazą „drapieżna, wulgarna, nieco chaotyczna” Jakub WiNIARSKI (2008), Janiak rzadko jest w swojej wulgarności drapieżna czy agresywna. Jasne, odczuwamy pokusę, by w taki sposób odczytać lekkość, z jaką rzuca się tu kurwami, chujami i innymi pierdoleniami; ale gdy przyjrzymy się konkretnym przykładom, dojdziemy 
szybko do wniosku, że wulgarne rejestry języka są u poetki skojarzone z zupełnie innym emocjonalnym odcieniem:

\section{częściej, częściej}

wydaje mi się, że zawsze są okna, przez które wchodzą zaciekawieni. ktoś tych okien nie zamknął, bezpieczeństwo najwyraźniej chuj.

wydaje im się, że jest wolność słowa. chyba nawet myślą, że wszyscy jesteśmy równi, nie podejrzewają że ktoś ich sprzedał, ktoś zaraz kupi.

właśnie okno zostaje zbitą szybą, bo tłum za bardzo chciał być. ktoś zawiśnie, kogoś zdegradują. dyscyplina najwyraźniej chuj.

(JANIAK, 2007, s. 9)

„Bezpieczeństwo chuj”, „dyscyplina chuj” - to wyraz nie oburzenia, a irytacji połączonej z rezygnacją. Podobnie wybrzmiewa otwierające wiersz no to chuj zdanie:

no to chuj, napisaliśmy sobie w mailu i wygląda na to, że wszyscy się z tym zgadzamy

(JANIAK, 2009, s. 42)

Fraza „chuj w dupę policji” (i jej logiczne rozwinięcie: „każdy policjant to skurwysyn") rzucona zostaje jeszcze gdzie indziej rytualnie, bo przecież nierytualnie użyć się jej nie da (jutro nie ma mnie $w$ pracy w kto zabił bambi? - JANIAK, 2009). Natomiast jeśli w wierszu Janiak pojawia się wprost, w anatomicznej postaci - domyślny znaczony dla znaczącego "chuj” - to najprędzej jako „fiut fioletowy jak wątróbka”, śmieszno-odrażający, godny najwyżej kpiny (wiersz dla królów, którzy zostali a powinni wisieć z frajerom śmierć... - JANIAK, 2007).

Dokładnie tym samym tonem, jakim kwituje „bezpieczeństwo chuj", Janiak mówi w wierszu inkwizycja, bezpośrednio poprzedzającym częściej, częściej:

co parę dni, co trafiam na okazję, jestem czarna i mam najpiękniejszy tyłek 
świata. noszę krzyż ze słoniem na szyi

i pierdolę wszystkich, jestem czarna

i pierdolę białych, jestem biała etc.

schylam się częściej, użyczam hebanu

na dziko.

(JANIAK, 2007, s. 8)

Sytuację rozbraja oczywiście owo „etc.”; Janiak po raz pierwszy (to jej debiutancka książka) mówi nam, co pierdoli, ale to - znów pierdolenie jakby bezwiedne, by nie powiedzieć: wymuszone. Dużo później, w zwęglonejjantar, przyzna co prawda wprost: „kosmos potrzebuje mojego wkurwienia" (ha ha śmierć ze zwęglonej jantar), ale w tej samej książce pomieści na przykład taki obrazek (kochany!):

hodowałeś z ojcowską dumą, rozciągałeś i doplatałeś te coraz to nowe dzielnice, akry, ugory, te nieużytki

między nami, gdy tymczasem ja również browar wolę, kochany! gdy tymczasem ja też pierwszy, drugi, trzeci, tyle że w biegu. i rzucam klątwy, wojny, katastrofy, bóle, wrzody, parchy i nigdy niegojące się rany. jak serce, kochany, jak kurwa serce!

(JANIAK, 2016, s. 4)

Owszem, wiersz pobrzmiewa ironicznie, ale ostatecznie „klątwy” związane zostają tu ze stanem odsłonięcia czy wrażliwości („nigdy niegojące się rany") oraz specyficznym rodzajem rezygnacji/desperacji/frustracji.

Wulgarna fraza poetki nie wynika z chęci prowokacji, nie jest w tym sensie wysilona, lecz stanowi świadomie przepracowane świadectwo zmęczenia bądź czegoś pokrewnego. Trudno uwierzyć, że tak konotowany „wkurw” miałby być na przykład narzędziem ukierunkowanej społecznej zmiany; to raczej wkurw z gatunku najbardziej codziennych, uporczywa, pozostająca zawsze z tyłu głowy frustracja rozproszona na setkę fraz celowo pozbawionych mocy przebicia - fraz wulgarnych, ale nie tak na serio wulgarnych. Owszem, to chuj i tamto chuj, i każdy X to skurwiel (a zwłaszcza, jak wiadomo, policjant), ale właściwie co z tego - wydaje się pytać Janiak. Gniew, o którym pisze, jawi się jako wybitnie niesprawczy, momentami wręcz rozpaczliwy - i ten gniew poetka dokumentuje bardzo wnikliwie, szczegółowo, konsekwentnie. 
Przyjrzyjmy się dokładniej przywołanej już symbolice ognia.

Ogień stanowi naturalny, oczywisty żywioł tego, co „drapieżne” i „chaotyczne”; związków tematu ognia z rewolucyjnym gniewem (ale też - ze świętym oburzeniem) omawiać nie trzeba. Płomieni, iskier etc. pojawia się w wierszach Janiak, jak wiadomo, dużo w mniejszym lub większym stopniu organizują one w zasadzie każdą książkę poetki, najwyraźniej do głosu dochodzą w centralnej dla zwęglonej jantar wszystkożernej tęczy, która sama jest nieoczywistą figurą światła-ognia.

Podobnie jak uogólnione hasło „wulgarność” ukryć może konkretny charakter czy specyfikę wulgarnej frazy Janiak, określenie jej wierszy - powiedzmy - pełnymi ognia ukrywałoby to, o jaki właściwie ogień chodzi. A jest to ogień nie porywczy i wybuchowy, ale powolny, pełznący, kroczący - raczej antycypowany (i będący nieraz źródłem lęku) niż ogień tu-i-teraz, ogień w działaniu. W wierszach Janiak częściej znajdziemy wspomniany już „grunt, który dawno spłonął" niż taki, który płonie na naszych oczach.

Dlatego, jak się zdaje, w wierszu zapalaj się lampo z frajerom śmierć... bardziej oczywista gramatycznie forma „zapal” zostaje zastąpiona niedokonaną ,zapalaj”:

Zapalaj się lampo, zapalaj.

Broń się, jak możesz walcz.

W nocy inaczej się stawia

Instrumenty, inne bolączki

Wsadza się w tył głowy.

(JANIAK, 2007, s. 30)

Wezwanie „zapalaj się” zostaje powtórzone jeszcze dwukrotnie, zaadresowane do „ciała” oraz „dnia”. Natomiast stronę dalej ogień pojawia się jako makabryczna i niespełniona fantazja:

iskra

chciałabym najbardziej, żeby człowiek

zdychał, a reszta się patrzyła

i tak do ostatniego zgromadzenia.

niech zdycha, a oni niech patrzą,

a potem do ostatniego zgromadzenia,

niech giną, reszta niech sobie patrzy. 
chciałabym, ale tak z iskrą, żeby wszystko poszło sprawnie.

(JANIAK, 2007, s. 31)

Iskra, jako płomień sprawny i sprawczy, pozostaje właśnie tym fantazją, wyobrażeniem, przeczuciem (nadzieją?). Nieco dalej w tym samym tomie (w wierszu lato tego roku -JANIAK, 2007, s. 40) zgliszcza okazują się rezultatem nie pożaru, ale upału: owego może najbardziej podstępnego ognia, ognia niepozornego i przebranego za światło (do którego Janiak ma stosunek dziwny i emocjonalnie dwuznaczny: „gdyby można było bać się światła jak dziecko boi się ciemności”pisze w wiatraku ze zwęglonej jantar - JANIAK, 2016, s. 53). Również w kodzie całego frajerom śmierć... mowa nie o paleniu się, ale o powolniejszym jakby (i konotującym raczej zmęczenie niż energię) wypalaniu:

kładziemy się spać,

gdy wysoko nad nami wypala się elektryczna lampa

(doma - JANIAK, 2007, s. 50)

W kino raz z kto zabił bambi? ów tlący się ogień okazuje się na poły erotyczny w swej naturze:

pykał popcorn, a my siedzieliśmy

z podmienionymi numerami.

zaczęło płonąć, iskrzyć, softporn.

(JANIAK, 2009, s. 40)

W enigmatycznym wierszu tytułowym zwęglonej jantar dostajemy z kolei dziwny, paradoksalny obraz „spalonego mrozu” - płomienia wypalającego się dosłownie na zimno, jakby bez zapału, bez „ognia”.

W utworze fantazyjny blurr z tego samego tomu powraca motyw upału i żaru:

za bardzo w środku też nie jest dobrze.

to wchłania informacje, mieli, wypluwa żar,

archipelagi rozpalonych kamieni. płynie na wioski,

po wioskach na miasta,

po miastach na puste miejsca po wioskach,

na ptaki bez piór pachnące ogniskiem.

$[\ldots]$ 
a jej nic się nie dzieje. trzydzieści stopni,

starsza pani odgania gazetą muchy,

delikatny wiatr. i nic, i nic nie dzieje się

dalej.

(JANIAK, 2009, s. 30)

Ten ogień interesuje poetkę najbardziej - taki, po którym „nic nie dzieje się".

Oczywiście w poezji Janiak płomienie nie zawsze tlą się tylko i iskrzą, zdarza im się też wystrzelić (choćby w wymownie zatytułowanym wierszu banały \& romanse z kto zabił bambi?). Ale charakterystyczny - i najczęstszy - jest właśnie ów płomień niewybuchowy, niedokonany, zimny. Owszem, dużo w wierszach autorki sugestii ognia, mówienia o ogniu; zwykle nie widzimy go jednak wprost - pojawia się jako ślad bądź fantazja, zalążek bądź przeczucie. Równie niespełniony, co gromadzący się w wierszu gniew.

Wszystkie poczynione tutaj rozważania zmierzają w kierunku jednego rozpoznania: sugestia wkurwu, oburzenia czy gniewu w wierszach Janiak skrywa coś, co ostatecznie właściwie wkurwem nie jest; coś, co jest nim prawie, co chciałoby się nim stać, ale nie może. To coś zmęczonego, niekonkluzywnego, wiecznie odwlekanego; coś, na czego trop wpadł w Zebrało się śliny Skurtys, gdy zauważał, że z czasem w poezji Janiak „słuszny »wkurw « zmienia się w resentyment, a oczyszczający wulgaryzm przechodzi w nihilistyczne zgorzknienie lub wsobność" (SkURTYs, 2016, s. 144). Teraz moglibyśmy wręcz pójść krok dalej i powiedzieć, że wulgaryzm poetki na żadnym etapie nie był faktycznie „oczyszczający” (podobnie jak ogień nie jest u niej oczyszczający), tylko zwodził nas i budził oczekiwania. W jakim celu? By odpowiedzieć na to pytanie, przywołajmy fragment jeszcze jednego wywiadu z autorką:

Agnieszka Budnik: Jeżeli spojrzeć na zwęglona jantar, to jest to poetycki głos składający się z wielu pomniejszych „złostek”, co sumuje się w poczuciu silnej i porażającej złości. Twoja najnowsza książka jest jednak dużo spokojniejsza (JANIAK, BUDNIK, 2019).

Wypowiedź to o tyle ciekawa, że łączy fantastyczne rozpoznanie z nieświadomym, jak się zdaje, interpretacyjnym uproszczeniem. Z jednej strony „złostki” idealnie nazywają tę szczególną, upartą postać wkurwu. Z drugiej - założenie, że „sumują się” one do „pora- 
żającej złości", nie tylko ignoruje niekonkluzywność i zrezygnowaną lekkość niby-wkurwu Janiak, lecz także pozbawia owe „złostki” wszystkiego, co wyjątkowe. Każdy gniew rozbić można na mniejsze „podgniewy”; nie każdy gniew musi zaś prowadzić do czegoś większego. Jak pokazałem, świadectw „sumowania się" gniewów trudno doszukiwać się u poetki - raczej, przeciwnie, na każdym kroku odbieramy sygnały, że nic tu nie zmierza jednoznacznie do końca, nie narasta, że ciągle wracamy z poetką do punktu wyjścia. „Końcowa faza frustracji”, o której Janiak mówiła w rozmowie ze Staśko (JANIAK, STAŚko, [b.r.]), wydaje się sugerować raczej dogasanie niż kulminację: końcowa faza to raczej faza terminalna niż finałowa.

„Złostki”, owe małe, rozproszone niby-gniewy, nazywają coś kluczowego dla poezji Janiak - o ile potraktujemy je jako formę docelową, a nie pośrednią. Tym czymś byłaby sama niemożność - z braku lepszego określenia - afektywnej akumulacji: przeistoczenia się rozproszonej frustracji i irytacji w jakieś bardziej wyraziste uczucie, stworzenia dla nich spójnego wyjaśnienia, spójnej logiki. Złostki pozostają złostkami, a jako takie rzucają wyzwanie interpretatorom - właśnie dlatego, że nie podlegają logice narastań, podsumowań i akumulacji.

Tak opisana niemożność afektywnej akumulacji pozostaje mocno związana z zasadniczo antynarracyjnym charakterem wierszy Janiak. Nie tyle stronią one od formuły wiersza narracyjnego, czy szerzej: konwencji wiersza-opowieści i wiersza-anegdoty, ile odwołują się do nich punktowo i pozornie, by podważyć i rozbić związane z nimi oczekiwania. Wiersze poetki, owszem, bardzo często opisują jakąś sytuację wyjętą ewidentnie z dłuższej historii, owej dłuższej historii nigdy jednak nie poznajemy; widzimy postaci (przede wszystkim samą narratorkę) ewidentnie obciążone poważnym bagażem, złożoną indywidualną historią, ale ich przeszłość praktycznie nigdy nie zostanie przed nami odkryta. Widać to w trybie krytycznoliterackiej recepcji Janiak - w czterech obszernych książkach dostaliśmy od niej ponad 200 długich wierszy o najróżniejszych mniej i bardziej codziennych tematach, dyskutujemy zaś, ja także, głównie o ogólnych kwestiach emocjonalno-afektywnych, rekonstruując pewien zasadniczy „stan” bohaterki; mimo iż wyraźna jest podmiotowa kreacja Janiak, wiemy o niej nadal zaskakująco niewiele, krążymy wciąż wokół tych samych tematów. Nie wynika to absolutnie z zagubienia interpretatorów, ale ze świadomej konstrukcji wiersza Janiak: zawsze momentalnego, zawsze wyjętego z kontekstu, zawsze sugerującego istnienie narracji, która pozostaje 
jednak bardzo wyraźnie poza naszym zasięgiem. To nawet nie tyle zwodzenie czytelnika - Janiak nigdy nie sugeruje bowiem, że nasza ciekawość zostanie zaspokojona - ile sposób na przekazanie pewnego wrażenia bezradności, niekonkluzywności, poczucia, że ostatecznie „nic nie dzieje się".

Opisany mechanizm - oparcia na zawsze urwanej i niemożliwej narracji, szkicowania historii, do której czytelnik nie ma ostatecznie dostępu - znajdziemy w wielu konkretnych wierszach. W przyjacielu z frajerom śmierćc.. widzimy historię dziwnej znajomości, zażyłości połączonej z chowaną urazą, skonkludowaną katastroficznym „już gdzieś tam do ciebie idzie ogień" (JANIAK, 2007, s. 5) - ale nie dowiemy się niczego na temat genezy „przyjaźni”, jej rozwoju, treści zatajonej skargi. W chodniku z kto zabił bambi? obraz wędrującej (powiedzielibyśmy - zgodnie z aktualną akademicką modą dryfującej) po mieście narratorki zostaje ciekawie zdenarratywizowany; konwencja kazałaby pokazać jakiś ruch, jakieś przesuwające się miejsca i obrazy, tymczasem Janiak w wierszu o miejskim spacerze uparcie stoi w miejscu. Czy inaczej: my widzimy ją w miejscu, widzimy ją bowiem tylko przez moment, z którego to momentu nie da się narracji wywieść (JANIAK, 2009, s. 23). Najwyraźniej jednak mechanizm opowieści bez opowieści poetka przedstawia bodajże w kulce, również z kto zabit bambi?:

rano wstałam, pobytam trochę $z$ wami a wieczorem położyłam się spać

za oknem kościół albo inny klasztor, coś pod oknem przestało się szamotać, coś pod oknem przestało się przyglądać.

o coś walczyłam z prawem i wygrałam drugi koniec miasta albo inny jego kawałek. coś przestało piskać, coś zaczęło się cofać odgadywać majaki wytarte w spodnie. ten fragment jest już bardzo brudny. a coś $i$ ktoś uprawiali rozmowę miłosną,

a za oknem kościół albo inny klasztor, za oknem jedno miasto albo drugie miasto. i przypomniało mi się coś bardzo ważnego,

że walczyłam $\mathrm{z}$ prawem $\mathrm{i}$ wygrałam drugi koniec miasta, a że było ciasno coś pod oknem spojrzało w inne głęboko 
i wypowiedziało poczucie sprawiedliwości.

a coś ma włosy tak jasne jak szkatułka

w której płonie największe serce świata.

albo największe ognisko kosmosu

albo kulka, mała złota kulka.

za oknem kosmos albo inny koniec.

(JANIAK, 2009, s. 30)

Wiersz, chociaż enigmatyczny, nie jest oczywiście kompletnie nieprzejrzysty; nieczytelna, przeczuwana tylko jest natomiast sama historia, zapisana tu za pomocą pustych miejsc: coś, ktoś, taki albo inny, takie albo drugie. O coś walczyła, jedno miasto albo drugie miasto, przypomniało jej się coś ważnego - dostajemy do rąk nawet nie tyle opowieść wybrakowaną, ile wspomnienie, ślad po opowieści; wrażenie, że kiedyś istniała jakaś opowieść, zredukowana teraz do śladu czy resztki w postaci pojedynczego, niespójnego obrazka.

Niemożność uspójnienia czy rozwinięcia narracji tłumaczy więc emocjonalne rozproszenie, czy raczej emocjonalną niekonkluzywność, wrażenie mnogości złostek raczej niż wyrazistego wkurwu. Narastający, konsekwentny gniew wymaga historii: akumulacji krzywd i buntów, refleksji i emocji. Tymczasem w poezji Janiak przesuwamy się od jednego urwanego wątku do innego, od jednego małego gniewu do kolejnego. Niemożność narratywizacji odczytywać możemy w kategoriach pokoleniowej diagnozy (brak stabilności odczuwany przez młody prekariat), politycznego komentarza na temat półperyferyjnej kondycji (niedostępność „własnych” tożsamościowych narracji) albo egzystencjalnej refleksji (symptom przewlekłej depresji i poczucia osamotnienia) - wszystkie trzy perspektywy wydają się zresztą uzasadnione i komplementarne. Niezależnie od tego, którą z nich uznamy za podstawową, to w tym miejscu gniew ściera się w wierszach Janiak z drugą kluczową afektywną siłą jej wierszy: ze smutkiem. Pozbawiona narzędzi narratywizowania świata bohaterka - bo już nie narratorka - wpada w szczególnego rodzaju rozpacz. To jednak temat na osobne rozważania.

Tymczasem można by się pokusić o otwarcie dwóch interpretacyjnych tropów.

Pierwszy dotyczyłby gniewu i (nie)możliwości dostrzeżenia wspólnotowej podmiotowości w poezji Janiak. Pisząc o polityczności literackiego „wkurwu”, często mamy na myśli wkurw eksplicytnie bądź implicytnie klasowy, a jeśli nie bezpośrednio klasowy, to będący wyrazem zbiorowego głosu - miejscem, w którym poeta bądź poetka mówi w imieniu nie tylko swoim, lecz całej wspólnoty skrzywdzonych. Jeśli wkurw jest polityczny, to wynika - ponownie - z pewnej 
narracji na temat tej wspólnoty, jej składu, tożsamości, historii i tak dalej. Potrzebuje opowieści o krzywdzie. W wierszach Janiak takich opowieści (w spójnej postaci) nie znajdziemy, podobnie jak nie znajdziemy silnych tożsamości ani silnych wspólnot: jej niby-narratorka jawi się raz po raz jako wyizolowana, odbijająca się od ludzi, w głębokim sensie samotna albo porzucona. Częściej obserwuje innych, ewentualnie wyobraża ich sobie, niż wchodzi z nimi w kontakt. Historia własnej traumy - depresji, głęboko nieudanych związków - nie pozwala narratorce nawiązać łączności. Inni ludzie sami jawią się w tej sytuacji jako naraz rozproszeni, mijający się i wrodzy, jak w niezatytułowanym, enigmatycznym wierszu z kto zabił bambi?:

banderola na dywanie. W końcu

sobie ich wszystkich odbiję.

Eksperyment przemawia na obcą korzyść, spotkania gumowych ust z górską przyrodą.

I zajebiście czuję, że boleśnie się mnie poucza. student socjologii,

studentka polonistyki, student metod ilościowych,

grafik na pół, programista javy na cały etat w małej warszawskiej firmie,

jakiś koleś, tak po prostu

i kurwa. Jedna z drugą, kiedy mijamy się w drzwiach zary.

(JANIAK, 2009, s. 5)

W tym kontekście poezja oparta na złostkach stawia tezę bardzo polityczną: rozbita, niedokończona podmiotowość, ewidentnie wychylona ku mnogości, ale niepotrafiąca ostatecznie wyjść poza jednostkową perspektywę - wielość wyizolowanych, zdesperowanych jednostek bez swojej opowieści, groteskowy tłum, który „za bardzo chciał być" (JANIAK, 2007, s. 21) - ma dostęp wyłącznie do równie rozbitych, rozproszonych form gniewu. Chciałoby się powiedzieć, że wkurw, owszem, jest (albo przynajmniej bywa) klasowy, natomiast podklasa może być tylko podkurwiona.

I drugi trop. Tak naszkicowana perspektywa mogłaby stać się punktem wyjścia nowego omówienia katastroficznych i profetycznych wątków poezji Janiak: słynnej wszystkożernej tęczy albo kończącego świata niepozornego „pyk” z wiersza o tym samym 
tytule (JANIAK, 2016). Stanowiłyby one już nie tyle przedłużenie gestów gniewu, ile sposób wyjścia z problematycznej sytuacji, z paraliżu i impasu. Złostki nie kumulują się w wielki gest oburzenia, nie dają same z siebie nadziei na zmianę - tym, co pozostaje, jest więc na poły duchowy (religijny? milenarystyczny?) impuls, gorzka nadzieja „tęczy”, która przełamie impas, bo coś musi się wreszcie zmienić. Albo inaczej: między złostkami a produktywnym gniewem nie ma logicznego przejścia, zastąpić je musi więc skok wiary. I dlatego Janiak ostatecznie mówi właśnie w języku wiary.

Poezja Janiak to poezja tysiąca urwanych - albo wręcz nie do końca napoczętych - narracji; buzującego, niekonkluzywnego gniewu, tlącego się ognia, nigdy niedokończonych relacji i rozbitych tożsamości. Wszystko to jest, oczywiście, rezultatem nie artystycznej porażki, ale świadomego i konsekwentnie prowadzonego literackiego projektu - Janiak udaje się wyjątkowo trafnie zmapować pewne historycznie, politycznie, pokoleniowo interesujące emocje i nastroje. Równocześnie poetka ukazuje fundamentalne mechanizmy pewnego rodzaju językowej improwizacji: wynikającej nie tyle z samego twórczego impulsu, ile z sytuacji niemożności i desperacji; improwizacji koniecznej, podejmowanej przez podmiot odarty z narracyjnej sprawczości.

\section{Bibliografia}

JANIAK Kamila, 2007: frajerom śmierć $i$ inne historie. [Ilustr. Marek SoBCZYK]. Warszawa: Staromiejski Dom Kultury.

JANIAK Kamila, 2009: kto zabił bambi? [Ilustr. Marek SobczyK]. Warszawa: Fundacja Modern Art Means Modern Artist Language (MAMMAL).

JaNiAK Kamila, Budnik Agnieszka, 2019: W stronę konkretu. Rozmowa z Kamilą Janiak. Tekst Agnieszka Budnik. „Kultura u Podstaw”. 24.01.2019. [Online:] https://kulturaupodstaw.pl/kamila-janiak-w-strone-konkretu/ [20.08.2019].

JANIAK Kamila, STAŚKo Maja, [b.r.]: I nic, i nic dzieje się dalej. [Z Kamilą Janiak rozmawia Maja Staśko]. „,biBLioteka”. Sierpień 2016. [Online:] https://www.biuroliterackie.pl/biblioteka/wywiady/nic-nic-dzieje-sie/ [20.08.2019].

JANIAK Kamila, 2016: zwęglona jantar. [Rysunki Grzegorz SzymA]. Warszawa: Staromiejski Dom Kultury. 
JaNIAK Kamila, 2018: wiersze przeciwko ludzkości. Autorka ilustr. Ola WasilewsKa. Poznań-Warszawa: Wydawnictwo Wojewódzkiej Biblioteki Publicznej i Centrum Animacji Kultury w PoznaniuStaromiejski Dom Kultury w Warszawie.

Kozıoє Paweł, [b.r.]: Kamila Janiak. Culture.pl. [Online:] https://culture. $\mathrm{pl} / \mathrm{pl} /$ tworca/kamila-janiak [20.08.2019].

SKURTYs Jakub, 2016: Ja-składnia. [Online:] https://www.biuroliterackie.pl/biblioteka/recenzje/ja-skladnia/[15.10.2019].

WiNIARSKI Jakub, 2008: Drapieżna, wulgarna, nieco chaotyczna. „Odra”, nr 2.

Paweł Kaczmarski

\section{Piss-offs, Little Fits of Pique, and the In-Between}

On Kamila Janiak's Poetry

Summary: The article is focused on the theme of anger in Kamila Janiak's poetry - its forms, types, and understanding that transpire as she develops her poetry. A paradigm of reception assumed herein as a departure point is the category of a "piss-off" (Polish vulgar noun wkurw, a strong sensation of anger), which is synonymous with intense and politically motivated indignation. The author of the article, however, attempts to show that Janiak's poetry has been for a long time defined by other affective registers; emotions and moods in a way supressed - restricted, unfulfilled, most of all: incapable of climaxing and of "exploding." The said state of affairs should be connected with the structure of individual and collective subjectivity appearing in Janiak's poetry, namely, a subject that is shattered and (also politically) dispersed, lacking any devices to develop a coherent narrative, with hardly any access to political forms of anger which frequently cannot exist without consistent narrative. Instead of being expressed by one's indignation, the said subject resorts to "little fits of pique" (a diminutive złostki is used here by Janiak), a series of minor, yet rapidly accumulating irritations, which do not find their outlet. This state of being affectively shattered may be seen in existential categories, but also political and generational ones.

Keywords: anger, indignation, narrative, multiplicity, affects 